\title{
Importance of plasma $E$ apolyprotein dosage, of genetic polymorphism and lipid profile in diabetic patients
}

\section{Importanța dozării apoliproteinei E plasmatice, a polimorfismului genetic și a profilului lipidic la pacienții diabetici}

Silviu Daniel MOLDOVAN ${ }^{1,2}$, Romana Olivia POPEȚIU ${ }^{1,2}$, Oana Lucia AMZA ${ }^{1,2}$, Luminiţa PILAT ${ }^{1,2}$, Maria PUȘCHIȚĂ ${ }^{1,2}$

${ }^{1}$ Facultatea de Medicină, Universitatea de Vest „Vasile Goldiș“, Arad, România

${ }^{2}$ Spitalul Clinic Judeţean de Urgenţă, Arad, România

\begin{abstract}
Apolipoproteine $E(A p o E)$ is known for its ability to suppress atherosclerosis. Besides its activity to remove the remaining lipoproteins from plasma, ApoE is also known for its direct influence on the numerous cells of the vascular walls, immune system and bone marrow. Recent research has shown that in addition to antiaterogenic properties, it also shows the property of suppressing myelopoiesis.
\end{abstract}

Keywords: apolipoprotein E, atherosclerosis, type 2 diabetes, genetic polymorphism, lipid profile

\section{REZUMAT}

Apolipoproteina E (ApoE) este cunoscută pentru abilitatea ei de a suprima ateroscleroza. Pe lângă activitatea sa de a îndepărta lipoproteinele remanente din plasmă, ApoE este cunoscută și pentru influența sa directă asupra numeroaselor celule ale pereților vasculari, asupra sistemului imunitar și măduvei osoase. Cercetări recente au evidențiat faptul că, pe lângă proprietățile antiaterogene, mai prezintă proprietatea de a suprima mielopoieza.

Cuvinte cheie: apolipoproteină E, ateroscleroză, diabet tip 2, polimorfism genetic, profil lipidic

\section{INTRODUCERE}

Apolipoproteina E umană este o componentă majoră a particulelor de lipoproteine, care, în condiţii fiziologice, este implicată în transportul plasmatic de colesterol. ApoE se găsește sub trei izoforme (E2, E3, E4) și face parte din familia apolipoproteinelor care, în condiţii patologice, sunt identificate în depozitul extracelular de amiloid, în diferite amiloidoze. Interesant este faptul că forma liberă lipidică a ApoE a fost identificată ca localizare alături de peptidul $A \beta$, în plăcile de amiloid din boala Alzheimer, iar izoforma ApoE4 este un factor de risc crucial în instalarea precoce a bolii Alzheimer $(2,3)$.

ApoE este o glicoproteină cu 299 de aminoacizi, făcând parte din toate clasele de lipoproteine, cum ar fi chilomicronii, lipoproteine cu densitate 
joasă (VLDL) și lipoproteine cu densitate înaltă (HDL). Este un membru al familiei de lipoproteine alături de ApoA-I, ApoA-II, Apo A-IV, Apo C-I, Apo C-II, Apo C-III. Fiecare clasă de apolipoproteine are funç̧ii distincte și participă activ la reţeaua specifică de lipoproteine.

ApoE umană are o sinteză primară în ficat, unde se găsește în cantităţi mari, dar este și o proteină aparţinând creierului și altor ţesuturi. Forma funcţională a proteinei este implicată în legăturile metabolice care asigură transportul și distribuţia la nivelul ţesuturilor a colesterolului plasmatic și a trigliceridelor, prin interacţiunea sa cu alte componente ale receptorilor de lipoproteine cu densitate joasă $(4,5,19)$.

Gena ApoE este localizată alături de genele Apo C1 și Apo C2, și prezintă 3 alele ApoE2, ApoE3, ApoE4 de pe cromozomul 19q13.2. Fiecare alelă prezintă o frecvenţă variată în rândul populaţiei umane, cu ApoE3 având cea mai mare pondere, de aproximativ $78 \%$. Datorită diferenţelor structurale ale acestor izoforme, ele posedă o capacitate diversă de a se lega de receptori, de aici și un rezultat variat în influenţarea metabolismului lipoproteic. ApoE3 și ApoE4 se leagă de LDL cu o afinitate crescută, în timp ce ApoE2 interacţionează cu receptorul în proporţie de doar $2 \%$. ApoE3 este cea mai comună izoformă ( $77 \%$ din populaţia caucaziană) și nu modifică metabolismul lipoproteinelor. ApoE4 este întâlnită la $15 \%$ din populaţie și poate duce la valori crescute ale concentraţiei LDL-C. ApoE2 este cea mai rară izoformă, poate fi corelată cu hipertrigliceridemia și poate contribui la accelerarea aterosclerozei. Polimorfismul genetic al ApoE poate influenţa și concentraţia în ser a ApoE; valori crescute au fost măsurate la purtătorii de ApoE2, iar valori scăzute - la cei cu ApoE4 $(6,7,8)$.

\section{CORELAȚIA DINTRE DIABET ŞI ALTE BOLI}

Nefropatia diabetică este o boală renală cronică progresivă, care apare la 1/3 dintre pacienţii cu diabet zaharat. Substratul histologic caracteristic este reprezentat de glomeruloscleroza diabetică. Clinic, se manifestă prin proteinurie, hipertensiune arterială și reducerea progresivă a funcţiei renale. Boala cronică de rinichi este în prezent una dintre cele mai importante afecţiuni de sănătate publică din cauza creșterii frecvenţei, a complicaţiilor, dar și a mortalităţii ca urmare a aterosclerozei accelerate. Una dintre cauzele principale de mortalitate la pacienţii diabetici este boala cardiovasculară în corelaţie cu dislipidemia, care se poate observa în stadii incipiente de insuficienţă renală asociate cu un grad scăzut de filtrare glomerulară.
Hipertrigliceridemia, acumularea de metaboliţi ai ApoE ce conţin lipoproteine (VLDL, IDL, LDL) și concentraţiile reduse de HDL pot duce la complicaţii ulterioare (19).

Surprinzător este faptul că ApoE are și unele proprietăţi antiaterogenice și chiar există date controversate între ApoE și riscul cardiovascular. În unele studii, s-a demonstrat că unii pacienţi cu boli cardiovasculare aveau concentraţii crescute de ApoE. Totuși, cercetătorii au subliniat faptul că distribuţia lipoproteinelor are o importanţă majoră în eveluarea riscului cardiovascular și doar concentraţia plasmatică a ApoE nu reprezintă un parametru cert pentru evaluarea riscului cardiovascular $(9,10,14,15)$.

Numeroase studii au indicat colesterolul ca fiind o componentă cheie a plăcii de aterom la nivel arterial, de aici și ipoteza patogenezei aterosclerozei. Studiile efectuate pe populaţie au demonstrat niveluri crescute de LDL colesterol și apoliporoteină B (ApoB100), structura principală proteică a LDL fiind direct asociată cu riscul de ateroscleroză și evenimente cardiovasculare. Leziunile arteriale cauzează disfuncţii endoteliale ce modifică ApoB, care conţine lipoproteine, și infiltrarea monocitelor în spaţiul subendotelial. Infiltrarea macrofagelor conduce la stres oxidativ și la secreţie de citokine/chemokine, cauzând oxidarea LDL, activare celulară endotelială și formarea plăcii de aterom. HDL, ApoA-I și ApoE endogenă previn inflamaţia și stresul oxidativ, dar, totodată, stimulează efluxul de colesterol pentru a reduce formarea leziunilor. Coexistenţa diabetului zaharat cu alţi factori, în particular dislipidemia, crește și mai mult riscul de deces prin boli cardiovasculare. Un tipar caracteristic, numit dislipidemie diabetică, constă în niveluri crescute ale trigliceridelor, niveluri scăzute ale HDL și lipemie postprandială, fiind des întâlnită la pacienţii cu diabet zaharat tip 2 sau sindrom metabolic $(11,12,13,20)$.

Prevalenţa dislipidemiei este mai crescută la pacienţii cu diabet zaharat de tip 2, dar tulburări în metabolismul lipoproteinelor pot fi întâlnite și la pacienţii cu diabet zaharat de tip 1. Pacienţii cu diabet zaharat de tip 1 slab controlat prezintă niveluri crescute de trigliceride din cauza reducerii activităţii lipoproteinlipazei în mușchi și adipocite. Deficitul de insulină este, de asemenea, asociat cu creșterea nivelurilor de LDL-C și ApoB100, din cauza faptului că expresia receptorilor de LDL este controlată în parte de insulină.

Fiziopatologia dislipidemiei diabetice nu este în totalitate înţeleasă, însă se cunoaște faptul că modificările la nivel plasmatic ale lipoproteinelor la pacienţii diabetici cresc postprandial și sunt mo- 
derate de deficite ale acţiunii insulinei și, consecutiv, hiperglicemie. Postprandial, acizii grași și colesterolul sunt absorbiţi de către celulele intestinale și încorporate ca trigliceride, esterii colesterolului, în chilomicroni, particule mari care sunt tot trigliceride $(16-18,20)$.

\section{CONCLUZII}

Pacienţii cu diabet zaharat prezintă tulburări complexe ale metabolismului proteic. Acestea sunt asociate cu ateroscleroză avansată a vaselor mari și risc înalt de boli cardiovasculare. Dovezi clare demonstrează efectele statinelor asupra ambelor prevenţii cardiovasculare (primare și secundare) la pacienţii diabetici. Reducerea evenimentelor cardiovasculare este corelată cu tratamentul medicamentos, dar și cu scăderea LDL colesterolului. Tratamentul celorlalţi factori - precum hipertensiunea arterială, hiperglicemia și obezitatea este la fel de important în reducerea riscului cardiovascular al acestor pacienţi.

\section{Mulțumiri}

Doamnei Simona Krämer și doamnei Marilena Diaconescu, profesori de limba engleză.

Conflict of interest: none declared Financial support: none declared

\section{BIBLIOGRAFIE}

1. Stevens PE, Levin A. Evaluation and management of chronic kidney disease: Synopsis of the kidney disease: Improving global outcomes 2012 clinical practice guideline. Ann Intern Med United States; 2013:158(11):824-832.

2. Visconti L, Benvenga $S$, Lacquaniti $A$, Cernaro V, Bruzzese A, Conti G et al. Lipid disorders in patients with renal failure: Role in cardiovascular events and progression of chronic kidney disease. J Clin Transl Endocrinol Netherlands; 2016;6:8-14.

3. Tsimihodimos V, Dounousi E, Siamopoulos $\mathrm{KC}$. Dyslipidemia in chronic kidney disease: An approach to pathogenesis and treatment. Am J Nephrol Switzerland; 2008; 28(6):950-975.

4. Krol E, Rutkowski B, Wroblewska M, Badzio T. Classification of lipid disorders in chronic hemodialyzed patients. Miner Electrolyte Metab Switzerland; 1996; 22(1-3):13-15.

5. Cwiklinska A, Cackowska M, Wieczorek E, Krol E, Kowalski R, Kuchta A et al. Progression of chronic kidney disease affects HDL impact on lipoprotein lipase (LPL)-mediated VLDL lipolysis efficiency. Kidney Blood Press Res Switzerland; 2018; 43(3):965-980.

6. Attman PO, Alaupovic P, Gustafson A. Serum apolipoprotein profile of patients with chronic renal failure. Kidney Int United States; 1987;32(3):360-380.

7. Davignon J, Gregg RE, Sing CF. Apolipoprotein E polymorphism and atherosclerosis. Arteriosclerosis United States; 1988; 8(1):1-21.

8. Heeren J, Beisiegel U, Grewal T. Apolipoprotein E recycling: Implications for dyslipidemia and atherosclerosis. Arterioscler Thromb Vasc Biol. United States; 2006; 26(3):440-450.

9. Mahley RW. Apolipoprotein E: Cholesterol transport protein with expanding role in cell biology. Science United States; 1988 Apr; 240(4852):620-640.

10. Greenow K, Pearce NJ, Ramji DP. The key role of apolipoprotein $\mathrm{E}$ in atherosclerosis. J Mol Med (Berl) Germany; 2005; 83(5):310-350.

11. Bahri R, Esteban E, Moral P, Hassine M, Ben Hamda K, Chaabani H. Apolipoprotein gene polymorphisms and plasma levels in healthy Tunisians and patients with coronary artery disease. Lipids Health Dis. England; 2008;7:46.

12. Lin CY, Duan H, Mazzone T. Apolipoprotein E-dependent cholesterol efflux from macrophages: kinetic study and divergent mechanisms for endogenous versus exogenous apolipoprotein E. J Lipid Res. United States; 1999;40(9):1600-1650.

13. Mahley RW, Apolipoprotein E: From cardiovascular disease to neurodegenerative disorders. J Mol Med (Berl). Germany; 2016;94(7):730-750.

14. Nguyen $D$, Dhanasekaran $P$, Nickel $M$, Nakatani R, Saito H, Phillips MC et al. Molecular basis for the differences in lipid and lipoprotein binding properties of human apolipoproteins E3 and E4. Biochemistry United States; 2010;49(51):10870-10900.

15. Vincent-Viry M, Schiele F, Gueguen R, Bohnet K, Visvikis S, Siest G. Biological variations and genetic reference values for apolipoprotein E serum concentrations: results from the STANISLAS cohort study. Clin Chem. United States; 1998; 44(5):955-966.

16. Morton AM, Koch M, Mendivil CO, Furtado JD, Tjonneland A, Overvad $\mathrm{K}$ et al. Apolipoproteins $\mathrm{E}$ and $\mathrm{CIII}$ interact to regulate $\mathrm{HDL}$ metabolism and coronary heart disease risk. $\mathrm{JCl}$ insight. United States; 2018;3(4).

17. Reilly M, Rader DJ. Apolipoprotein E and coronary disease: A puzzling paradox. PLoS Med United States; 2006 Jun; 3(6):e258.

18. van Vliet $P$, Mooijaart SP, de Craen AJM, Rensen PCN, van Heemst D, Westendorp RGJ. Plasma levels of apolipoprotein $E$ and risk of stroke in old age. Ann N Y Acad Sci. United States; 2007;1100:135-150.

19. Corsetti JP, Gansevoort RT, Bakker SJL, Dullaart RPF. Apolipoprotein E levels and apolipoprotein $\mathrm{E}$ genotypes in incident cardiovascular disease risk in subjects of the prevention of renal and vascular end-stage disease study. J Clin Lipidol United States; 2016;10(4):840-855.

20. Jaiswal M, Schinske A, Pop-Busui R. Lipids and lipid management in diabetes. Best Pract Res Clin Endocrinol Metab. 2014 Jun; 28(3):325-38. 